\title{
Hubungan Reward dan Supervisi dengan Pelaksanaan Pelayanan Keperawatan Syariah
}

\section{Correlation between Reward and Supervision with The Implementation of Sharia Nursing Services}

\author{
Dyah Wiji Puspitasari ${ }^{1}$, Muhammad Abdurrouf ${ }^{2}$, Maya Dwi Yustini ${ }^{3}$, \\ Retno Issroviatiningrum ${ }^{4}$, Bayu Anggileo Pramesona ${ }^{5}$ \\ ${ }_{1,2,3,4}$ Fakultas Ilmu Keperawatan, Universitas Islam Sultan Agung Semarang, Indonesia \\ ${ }^{5}$ Program Studi Profesi Ners, Universitas Muhammadiyah Pringsewu Lampung, Indonesia
}

\section{ARTICLE INFO}

\section{Article history}

Received date

03 August 2020

Revised date

12 Oct 2020

Accepted date

14 Oct 2020

\section{Keywords:}

Reward;

Sharia nursing services;

Supervision.

\section{Kata kunci:}

Reward;

Pelayanan keperawatan syariah;

Supervisi.

\section{ABSTRACT/ ABSTRAK}

Reward and supervision are important parts in implementing the quality of sharia-based nursing services. The quality or quality of sharia services at RSISA is in a good category, but it takes efforts to maintain and improve continuously. One of these efforts is by increasing rewards and supervision. The purpose of this study is to analyze the relationship between reward and supervision with the implementation of sharia nursing services. The subjects of this study were inpatients at Sultan Agung Islamic Hospital Semarang with a sampling technique that is simple random sampling with 96 respondents. Data analysis techniques in this study used the Spearman correlation statistical test. The results showed that there was a relationship between reward and the implementation of sharia nursing services with a p-value of 0,05 and there was a relationship between supervision with the implementation of sharia nursing services with a p-value of 0,01 . The results of this study were expected to be considered by hospital policy stakeholders to review the giving of rewards for nurses and the implementation of work supervision to nurses to improve the quality of sharia-based nursing services.

\begin{abstract}
Reward dan supervisi menjadi bagian penting dalam pelaksanaan mutu pelayanan keperawatan berbasisi syariah. Mutu atau kualitas pelayanan syariah di RSISA berada dalam kategori baik, tetapi butuh upaya untuk mempertahankan dan meningkatkan secara terus menerus. Salah satu upaya tersebut dengan meningkatkan reward dan supervisi. Tujuan penelitian ini adalah menganalisis hubungan reward dan supervisi dengan pelaksanaan pelayanan keperawatan syariah. Subjek penelitian ini adalah pasien rawat inap di Rumah Sakit Islam Sultan Agung Semarang dengan tehnik sampling yaitu simple random sampling dengan jumlah 96 responden. Teknik analisis data dalam penelitian ini menggunakan uji statistik sperman correlation. Hasil penelitian menunjukan bahwa terdapat hubungan antara reward dengan pelaksanaan pelayanan keperawatan syariah dengan nilai $p$-value 0,05 dan terdapat hubungan antara supervisi dengan pelaksanaan pelayanan keperawatan syariah dengan nilai $p$-value 0,01 . Hasil penelitian ini diharapkan dapat menjadi pertimbangan para pemangku kebijakan rumah sakit untuk meninjau ulang pemberian reward para perawat dan dan pelaksanaan supervisi kerja pada perawat dalam upaya peningkatan kualitas pelayanan keperawatan berbasis syariah.
\end{abstract}

Corresponding Author:

Dyah Wiji Puspita Sari

Fakultas Ilmu Keperawatan, Universitas Islam Sultan Agung Semarang, Indonesia

Email: daiyah_04@yahoo.com

\section{PENDAHULUAN}

Maqashid syariah (tujuan diadakannya syariah) yaitu seperti penjagaan agama, jiwa, keturunan, akal dan penjagaan harta, merupakan prinsip dalam pengelolaan yang diterapkan oleh rumah sakit syariah. Rumah sakit syariah dijalankan berpedoman pada fatwa dewan syariah nasional majelis ulama Indonesia yang telah ditetapkan pada peraturan No.107/DSN- 
MUI/X/2016 yang menjelaskan tentang pedoman penyelenggaraan Rumah Sakit berdasarkan prinsip syariah. Salah satu standar dalam sertifikasi Rumah Sakit Syariah adalah adanya pelayanan minimal yang wajib dilaksanakan di rumah sakit syariah (Mukisi, 2017).

Menurut Ayuningtyas (2008 dalam Oktariana, 2009), Rumah sakit yang berpedoman pada prinsip syariah memiliki tanggung jawab yang besar tidak hanya sekedar memberikan pelayanan kesehatan kepada pasien. Namun, pelayanan kesehatan yang diberikan dengan upaya untuk menjaga akidah, ibadah, dan serta muamalah sesuai dengan nilai-nilai Islam.

Kompetisi yang semakin ketat dan masyarakat sebagai pelanggan yang memiliki tuntutan serta pilihan pilihan yang selektif dapat mempengaruhi pertumbuhan rumah sakit, sehingga hal ini merupakan suatu taantangan yang akan mempengaruhi keberlanjutan suatu rumah sakit (Priyadi, 2015). Tantangan seperti ini mengharuskan para pelaku pelayanan kesehatan untuk berkompetisi dengan melakukan perubahan strategi dan perbaikan serta peningkatan kualitas pelayanan (Ravichandran, 2010).

Hasil penelitian yang dilakukan oleh Abdurrouf \& Rosalia (2018) menunjukkan adanya hubungan antara pelayanan syariah dalam bidang keperawatan dengan tingkat kepuasan pasien yang menunjukkan bahwa sebagian besar responden menyatakan puas dengan pelayanan syariah dalam bidang keperawatan yaitu sebanyak 37 responden $(28,5 \%)$.

Reward merupakan penghargaan atau hadiah yang diberikan atas keberhasilan yang telah dicapai. Reward tersebut dapat bersifat financial (pemberian uang, hadiah) dan nonfinansial (ucapan terima kasih, pujian, isi kerja dan lingkungan kerja). Reward dalam bentuk finansial saat ini masih menduduki peringkat teratas dibandingkan dengan nonfinansial. Reward ini sangat penting untuk dilakukan untuk meningkatkan kinerja perawat pelaksana. Penghargaan juga merupakan salah satu aspek yang berarti bagi pegawai, karena bagi individu atau pegawai besarnya penghargaan mencerminkan ukuran nilai karya mereka diantara para pegawai itu sendiri, keluarga, dan masyarakat.

Hail evaluasi kondisi kerja perawat di Indonesia saat ini masih bbelum memuaskan. Hal ini dapat dilihat dari pemberian sistem reward rumah sakit yang masih rendah baik dari rumah sakit negeri dan swasta. Kondisi ini yang secara otomatis mempengaruhi mutu pelayanan rumah sakit. Faktor yang dapat mempengaruhi kinerja petugas tadi, antara lain gaji yang kurang memadai. Rendahnya imbalan jasa bagi perawat selama ini juga mempengaruhi kinerja perawat (Rahayu, 2013).

Sistem penghargaan dibuat dengan beberapa tujuan, diantaranya untuk meningkatkan produktivitas kerja karyawan, meningkatkan disiplin kerja, dan menurunkan absensi karyawan, meningkatkan loyalitas dan menurunkan kerja karyawan, memberikan ketenangan, keamanan, kesehatan dan kesejahteraan karyawan, memperbaiki kondisi fisik, mental dan sikap karyawan, mengurangi konflik serta menciptakan suasana yang harmonis serta mengefektifkan pengadaan karyawan (Simamora 2004.

Sementara seorang manajer yang efektif juga akan menggunakan sistem pengakuan dan upaya penghargaan untuk menggalakkan perilaku kerja yang dikehendaki serta untuk mempertahankan karyawan potensial (Marquis \& Huston, 2009). Dalam pelaksanaannya manajer melaksanakan kegiatan supervisi untuk meningkatkan kualitas pelayanan.

Supervisi dan evaluasi memegang peranan penting dalam manajemen serta keseluruhan tanggung jawab pemimpin. Pemimpin dibutuhkan dalam pengelolaan asuhan keperawatan dengan memiliki kemampuan manajemen dari perawat profesional. Hal ini menjadikan seorang manajer keperawatan atau seorang perawat profesional diharapkan mempunyai kemampuan dalam supervisi dan evaluasi. Tujuan penelitian ini adalah menganalisis hubungan reward dan supervisi dengan pelaksanaan pelayanan keperawatan syariah.

\section{METODE}

Jenis penelitian ini adalah survey analitik dengan pendekatan cross sectional untuk mengetahui hubungan (korelasi) antara 2 variabel. Penelitian ini populasinya adalah semua perawat pelaksana yang ada di Ruang Rawat Inap Rumah Sakit Islam Sultan Agung Semarang bulan Oktober tahun 2019 yaitu sejumlah 126 perawat. Jumlah sampel penelitian ini adalah 96 responden. Teknik sampling yang digunakan dalam penelitian ini menggunakan teknik simple random sampling.

Instrumen yang digunakan dalam penelitian ini adalah berupa kuesioner dengan menggunakan skala likert. Instrumen penelitian ini adalah kuesioner yang terdiri dari tiga bagian yaitu: bagian A, merupakan kuesioner tentang 
identitas responden, bagian $\mathrm{B}$, merupakan kuesioner tentang supervisi, bagian C, merupakan kuesioner tentang reward atau penghargaan, bagian $\mathrm{D}$, merupakan checklist tentang pelaksanaan pelayanan keperawatan syariah.

Uji validitas dan reliabilitas dilaksanakan di RSI NU Demak dengan jumlah responden $30 \%$ dari jumlah sampel yaitu 32 responden dengan nilai $r$ tabel 0,349 Hasil uji validitas menunjukkan instrument pelaksanaan pelayanan keperawatan syariah 34 pernyataan valid dan 8 pernyataan tidak valid, instrument reward 13 pernyataan valid dan 6 pernyataan tidak valid, instrument supervisi 21 pernyataan valid dan 4 pernyataan tidak valid. Sedangkan uji reliabilitas didapatkan nilai cronbach alpha untuk instrument reward 0,767 , instrument supervise 0,97 dan instrument pelaksanaan palayanan keperawatan syariah 0,94 .

Analisa yang digunakan dalam penelitian ini menggunakan uji statistik spearman correlation. Analisa multivariat yang digunakan dalam penelitian ditentukan dengan uji statistik regresi linier berganda. Penelitian ini telah lolos uji etik dari komite etik Fakultas Ilmu Keperawatan UNISSULA Semarang dengan Nomor: 259/A.1-S1/FIK-SA/II/2020.

\section{HASIL}

Tabel 1. Distribusi Respoden Berdasarkan Karakteristik Responden

\begin{tabular}{lrr}
\hline \multicolumn{1}{c}{$\begin{array}{c}\text { Karakteristik } \\
\text { Responden }\end{array}$} & Jumlah & \% \\
\hline Jenis Kelamin & & \\
Perempuan & & 71,9 \\
Laki-laki & 27 & 28,1 \\
\hline Umur & & \\
$17-25$ & 18 & 18,75 \\
$26-35$ & 60 & 62,5 \\
$36-45$ & 18 & 18,75 \\
\hline Pendidikan & & \\
D3 & 91 & 94,8 \\
Ners & 5 & 5,2 \\
\hline Status Pernikahan & & \\
Menikah & 81 & 84,4 \\
Belum menikah & 15 & 15,6 \\
\hline
\end{tabular}

Tabel 1 menunjukkan bahwa sebagian besar responden berjenis kelamin perempuan yaitu sejumlah 69 (71,9\%), sebagian besar responden berumur antara 26-35 tahun sejumlah $60(62,5 \%)$, sebagian besar responden berpendidikan D3 Keperawatan yaitu sejumlah 91 orang $(94,8 \%)$, sebagian besar responden statusnya sudah menikah yaitu sebanyak 81 orang $(84,4 \%)$.
Tabel 2. Distribusi Responden Berdasarkan Pemberian Reward, Pelaksanaan Supervisi, dan Pelaksanaan Pelayanan Keperawatan Syariah

\begin{tabular}{lcc}
\hline \multicolumn{1}{c}{ Variabel } & Jumlah & \% \\
\hline Reward & & \\
Cukup & 39 & 40,6 \\
Baik & 57 & 59,4 \\
Jumlah & 96 & 100 \\
\hline Supervisi & & \\
Cukup & 12 & 12,5 \\
Baik & 84 & 87,5 \\
Jumlah & 96 & 100 \\
\hline Pelayanan Keperawatan Syariah \\
Cukup & 27 & 21,9 \\
Baik & 69 & 78,1 \\
Jumlah & 96 & 100 \\
\hline
\end{tabular}

Pada tabel 2 ditemukan data bahwa sebagian besar responden menyatakan pemberian reward baik sebesar 57 orang $(59,4 \%)$, sedangkan responden menyatakan pemberian reward cukup sebanyak 39 orang $(40,6 \%)$. Pada pelaksanaan supervisi, sebagian besar responden menyatakan pelaksanaan supervisi baik sebesar 84 orang $(87,5 \%)$, sedangkan responden menyatakan pelaksanaan supervisi cukup sebanyak 12 orang $(12,5 \%)$. Sedangkan pada pelaksanaan keperawatan syariah sebagian besar responden melaksanakan dengan baik sebesar 69 orang $(78,1 \%)$, sedangkan yang melaksanakan cukup baik sebanyak 27 orang $(21,9 \%)$.

Tabel 3. Uji Normalitas Variabel Reward, Supervisi dan Pelaksanaan Pelayanan Keperawatan Syariah

\begin{tabular}{lrr}
\hline \multicolumn{1}{c}{ Variabel } & $\begin{array}{c}\text { Kolmogorov- } \\
\text { Smirnov }\end{array}$ & $\begin{array}{c}\text { Shapiro- } \\
\text { Wilk }\end{array}$ \\
\hline Reward & 0,00 & 0,00 \\
Supervisi & 0,00 & 0,00 \\
Pelayanan & 0,00 & 0,01 \\
keperawatan Syariah & & \\
\hline
\end{tabular}

Tabel 3 menunjukkan bahwa variabel reward, supervisi dan pelaksanaan pelayanan keperawatan syariah didapatkan nilai $p$-value $<0,05$ artinya data variabel pada tabel 3 berdistribusi tidak normal, sehingga uji statistik yang digunakan adalah uji Spearman.

\begin{tabular}{lcc}
$\begin{array}{l}\text { Tabel 4. Uji Statistik Hubungan Antara Reward } \\
\text { dengan }\end{array}$ & $\begin{array}{c}\text { Pelaksanaan } \\
\text { Keperawatan Syariah }\end{array}$ & Pelayanan \\
\hline \multicolumn{1}{c}{ Variabel } & $\begin{array}{c}\boldsymbol{p} \text { - } \\
\text { value }\end{array}$ & $\begin{array}{c}\text { Koefisien } \\
\text { korelasi }\end{array}$ \\
\hline $\begin{array}{l}\text { Hubungan antara } \\
\begin{array}{l}\text { Reward dengan } \\
\text { Pelaksanaan Pelayanan } \\
\text { Keperawatan Syariah }\end{array}\end{array}$ & 0,05 & 0,486 \\
\hline
\end{tabular}


Tabel 4 menunjukkan bahwa uji statistik hubungan antara reward dengan pelaksanaan pelayanan keperawatan syariah dengan menggunakan uji Spearman didapatkan nilai $p$ value 0,05 artinya ada hubungan antara reward dengan pelaksanaan pelayanan keperawatan syariah dengan nilai koefisien korelasi 0,486 menunjukkan adanya hubungan yang cukup kuat antar kedua variabel.

Uji statistik untuk mengetahui hubungan reward dengan pelaksanaan keperawatan syariah menggunakan uji Spearman menunjukkan $p$ value $0,05(\leq 0,05)$ artinya Ho ditolak dan $\mathrm{H} 1$ diterima hal ini menunjukkan adanya hubungan antara reward dengan pelaksanaan keperawatan syariah, adapun hasil koefisien korelasi menunjukkan angka 0,486 dan arah hubungannya positif,

\begin{tabular}{lcc} 
Tabel 5. Uji Statistik & \multicolumn{2}{c}{ Hubungan antara } \\
Supervisi & dengan & Pelaksanaan \\
Pelayanan Keperawatan & Syariah \\
\hline \multicolumn{1}{c}{ Variabel } & $\begin{array}{c}\boldsymbol{p} \text { - } \\
\text { value }\end{array}$ & $\begin{array}{c}\text { Koefisien } \\
\text { korelasi }\end{array}$ \\
\hline $\begin{array}{l}\text { Hubungan antara } \\
\text { Supervisi dengan }\end{array}$ & 0,01 & 0,451 \\
$\begin{array}{l}\text { Pelaksanaan Pelayanan } \\
\text { Keperawatan Syariah }\end{array}$ & & \\
\hline
\end{tabular}

Tabel 5 menunjukkan bahwa uji statistik hubungan antara supervisi dengan pelaksanaan pelayanan keperawatan syariah dengan menggunakan uji Spearman didapatkan nilai $p$ value 0,01 artinya ada hubungan antara supervisi dengan pelaksanaan pelayanan keperawatan syariah dengan nilai koefisien korelasi 0,451 menunjukkan adanya hubungan yang cukup kuat antar kedua variabel.

Hasil uji statistik untuk mengetahui hubungan supervisi dengan pelaksanaan keperawatan syariah menggunakan uji Spearman menunjukkan $p$-value $0,01 \quad(<0,05)$ artinya Ho ditolak dan $\mathrm{H} 1$ diterima hal ini menunjukkan adanya hubungan antara supervisi dengan pelaksanaan keperawatan syariah, adapun hasil koefisien korelasi menunjukkan angka 0,451.

\section{PEMBAHASAN}

Hasil penelitian menunjukkan bahwa sebagian besar responden berjenis kelamin perempuan yaitu sejumlah $69(71,9 \%)$. Wanita diidentikkan dengan lemah lembut, sabar dan peduli (Yanti dan Warsito, 2013), Perawat wanita diharapkan dapat meberikan pelayanan keperawatan dengan sabar, lebih peduli dan lemah lembut, serta dapat memberikan pelayanan keperawatan syariah yang baik kepada pasien.

Responden dalam penelitian ini mayoritas berusia 20-35 tahun. Nursalam, (2015) menjelaskan umur 20-35 tahun merupakan umur dimana seseorang memiliki kekuatan fisik yang baik sehingga perawat lebih cekatan dan terampil dalam melakukan tindakan, sehingga pasien mendapatkan penanganan yang cepat saat membutuhkan bantuan. Semakin meningkat usia seseorang maka dalam melaksanakan pekerjaan akan semakin bijak dalam mengambil keputusan, bertanggungjawab, mampu mengendalikan emosi, berfikir rasional dan lebih toleran terhadap orang lain (Kumajas, Marouw, Bawotong, 2014), rentang usia 25-30 tahun, pada usia tersebut perawat lebih produktif dalam memberikan asuhan keperawatan, semakin usia meningkat perawat akan lebih bertanggungjawab, toleran dan bijak dalam mengambil keputusan.

Pendidikan responden dalam penelitian ini mayoritas adalah D3 Perawat. Pendidikan perawat yang tinggi akan meningkatkan motivasinya untuk melakukan pekerjaan lebih baik karena semakin meningkatnya wawasan keilmuannya dan dapat memanfaatkan sarana dan prasarana lebih baik dalam melakukan tindakan keperawatan (Wawan dan Dewi, 2010). Pendidikan seorang perawat mempengaruhi sikap dan perilakunya dalam melakukan pelayanan keperawatan.

Responden dalam penelitian ini mayoritas sudah menikah. Perawat yang sudah menikah memiliki anggapan bahwa pekerjaan tetap adalah sesuatu yang berharga dan penting, mayoritas perawat yang sudah menikah memiliki tingkat kepuasan dan loyalitas yang lebih tinggi, bertanggung jawab serta memiliki kinerja yang lebih baik (Kumajas, Marouw, Bawotong, 2014), meskipun disisi lain perawat yang sudah menikah memiliki tingkat stres dan tanggung jawab lebih tinggi daripada perawat yang belum menikah karena perawat yang telah menikah memiliki peran dan tanggung jawab sebagai istri/suami di rumah tangganya (Widiharti, 2016).

Hasil penelitian menunjukkan responden sebagian besar menyatakan bahwa reward yang diberikan kepada perawat sudah baik. Reward merupakan bentuk balas jasa yang diberikan oleh rumah sakit karena pekerjaan yang dilakukan oleh perawat berupa pembayaran uang secara langsung seperti gaji, upah, bonus dan insentif, dan dapat berupa pembayaran yang tidak langsung seperti asuransi, liburan yang dibiayai oleh rumah sakit reward yang diberikan kepada perawat berpengaruh kepada kedisiplinan perawat (Kristianto \& Santoso, 2013), perawat 
juga menunjukkan komunikasi yang baik dengan diberikannya reward (Prestyaningtyas, 2015)

Reward yang diberikan oleh rumah sakit baik berupa finansial (upah/ gaji, insentif, bonus, asuransi, liburan) maupun non finansial akan meningkatkan kinerja perawat, karena perawat akan merasa bahwa hasil karyanya dihargai oleh rumah sakit, sehingga perawat akan meningkat kedisiplinannya dan akan meningkatkan komunikasi terapeutik perawat.

Hasil penelitian berikutnya menunjukkan bahwa sebagian besar responden menyatakan bahwa pelaksanaan supervisi dilakukan dengan baik. Supervisi merupakan pemberian sumbersumber yang dibutuhkan oleh perawat dalam menyelesaikan tugasnya dalam rangka mencapai tujuan yang telah ditetapkan, dengan dilakukan supervisi maka kendala yang dihadapi oleh perawat dapat diketahui sehingga masalah yang muncul dapat diselesaikan dengan baik, bukan mencari-cari kesalahan perawat (Arwani \& Supriyanto, 2005).

Manfaat dilakukannya supervisi dapat berupa kepuasan bagi manajer/pimpinan, perawat dan juga pasien. Supervisi yang dilakukan dengan baik merupakan bentuk dukungan dari lingkungan untuk meningkatkan kualitas kerja perawat (Yanti dan Warsito, 2013), supervisi dapat meningkatkan pertumbuhan dan perkembangan perawat dalam keahlian dan kecakapan perawat dalam asuhan keperawatan (Suyanto, 2008).

Supervisi merupakan bantuan atau pemberian sumber-sumber yang dibutuhkan oleh perawat dalam menyelasaikan pekerjaannya berupa pemberian asuhan keperawatan kepada pasien, sehingga dapat meningkatkan kepuasan perawat, pimpinan dan akhirnya berdampak pada kepuasan pasien, supervisi juga dapat meningkatkan kualitas pelayanan keperawatan.

Hasil penelitian menunjukkan bahwa sebagian besar responden menunjukkan pelayanan keperawatan syariah dalam kategori baik. Hasil penelitian ini sejalan dengan penelitian sebelumnya oleh Abdurrouf dan Rosalia (2018) menunjukkan bahwa pelaksanaan pelayanan keperawatan berbasis syariah dalam kategori baik.

Pelayanan Islami memiliki pengaruh yang dapat menciptakan suasana yang tentram kepada pasien, pelayanan syariah juga dapat meningkatkan kepuasan pasien (Hafid, 2016) yang berdampak kepada loyalitas pasien, sehingga akan menggunakan rumah sakit kembali jika sakit dan merekomendasikan orang lain untuk menggunakan rumah sakit dimana dia dirawat (Sari, dkk., 2018).
Rumah Sakit Islam Sultan Agung merupakan rumah sakit yang sudah terakreditasi syariah, dimana perawat sudah terlatih untuk memberikan pelayanan syariah, pelayanan syariah berdampak kepada kepuasan pasien sehingga dengan melaksanakan pelayanan keperawatan syariah yang baik maka akan meningkatkan kepuasan pasien.

Hasil uji statistik hubungan antara reward dengan pelaksanaan pelayanan keperawatan syariah didapatkan nilai p-value 0,05 yang artinya ada hubungan antara reward dengan pelaksanaan pelayanan keperawatan syariah dengan nilai koefisien korelasi 0,486. Hal ini menjelaskan bahwa ada hubungan yang cukup kuat antara reward dengan pelaksanaan keperawatan syariah, yaitu semakin baik reward dilakukan maka semakin baik pelayanan keperawatan syariah yang dilakukan oleh perawat kepada pasien, demikian juga sebaliknya.

Hasil penelitian ini sejalan dengan penelitian yang dilakukan oleh Didimus, Indar, Asiah Hamzah (2013), tentang "Hubungan pemberian reward dengan kedisiplinan perawat diruang rawat inap Rumah Sakit Ibnu Sina YBWUMI Makassar," didapatkan hasil bahwa pemberian imbalan/reward berpengaruh terhadap kedisiplinan perawat. Penelitian ini juga senada dengan penelitian yang dilakukan oleh Juliati (2018) berjudul hubungan antara reward dengan kinerja perawat di RSUD Tanjungpura bahwa reward berpengaruh terhadap kinerja perawat.

Reward yang diterima oleh perawat pelaksana dari RS adalah biasanya berupa gaji pokok, insentif/ jasa pelayanan, dan tunjangan fungsional, serta pengembangan karir (Rahayu dan Dewi, 2017) Menurut Singodimedjo \& Markum (2009) mengatakan bahwa besar kecilnya reward yang diberikan oleh perusahaan/pemberi kerja akan memberikan pengaruh terhadap kedisiplinan karyawan karena pegawai/karyawan merasa bahwa imbalan yang diberikan oleh perusahaan adalah kompensasi dari pekerjaan atau hasil karya yang dilakukannya.

Adanya hubungan antara supervisi dengan pelaksanaan keperawatan syariah dengan hasil koefisien korelasi menunjukkan angka 0,451 dan arah hubungannya positif, hal ini menjelaskan bahwa ada hubungan yang cukup kuat antara supervisi dengan pelaksanaan keperawatan syariah, yaitu apabila supervisi dilakukan dengan baik maka pelayanan keperawatan syariah akan semakin baik, demikian juga sebaliknya.

Hasil penelitian ini sejalan dengan penelitian yang dilakukan oleh Wirawan, Novitasari, Wijayanti (2013), dimana hasil 
penelitian menunjukkan adanya hubungan signifikan antara supervisi kepala ruang dengan kinerja perawat dalam pendokumentasian asuhan keperawatan, hasil penelitian ini juga sejalan dengan penelitian yang dilakukan oleh Yanti dan Warsito, (2013) bahwa supervisi yang dilakukan dengan baik dapat memberikan dukungan kepada perawat untuk meningkatkan kualitas kerja perawat. Menurut Majid dan Sani (2016) supervisi yang dilakukan oleh kepala ruang kepada perawat pelaksana berpengaruh signifikan terhadap kinerja perawat.

Adanya hubungan yang signifikan antara supervisi dengan pelaksanaan pelayanan keperawatan syariah yang dilakukan perawat di Rumah Sakit Islam Sultan Agung Semarang dikarenakan adanya bimbingan, bantuan dan kesempatan yang diberikan oleh pimpinan/manajer keperawatan maka perawat akan mudah

\section{DAFTAR PUSTAKA}

Abdurrouf \& Rosalia. (2018). Pelayanan syariah bidang keperawatan dengan kepuasan pasien di rumah sakit. Jurnal NURSCOPE, 2018, vol.1, No.1. http://jurnal.unissula.ac.id/index.php/unc/ article/view/2862

Arwani \& Supriyanto. (2005). Manajemen Bangsal Keperawatan. Jakarta: EGC.

Didimus, S., Indar, \& Hamzah A. (2013), Hubungan pemberian reward dengan kedisiplinan perawat diruang inap RS IBNU SINA YBW- UMI Makassar. [Skripsi]. Makassar: Fakultas Kesehatan Masyarakat, Universitas Hasnuddin.

Hafid, H. P. (2016). Pengaruh Pelayanan Dengan Prinsip-Prinsip Syariah Terhadap Kepuasan Pasien Pada RSI Ibnu Sina Makassar. [Skripsi]. Makassar: Fakultas Ekonomi dan Bisnis Islam Jurusan Ekonomi Islam, Universitas Islam Negeri (UIN) Alauddin Makassar.

Juliati. (2018). Hubungan Reward Dengan Kinerja Perawat Di Rumah Sakit Umum Daerah Tanjung Pura. Jurnal Keperawatan Priority, Vol 1, No. 1, Januari $2018 \quad$ ISSN 2614-4719. http://jurnal.unprimdn.ac.id/index.php/ju kep/article/view/47/31

Kristianto \& Santoso. (2013). Hubungan Pemberian Reward Ucapan Terima Kasih Dengan Kedisiplinan Waktu Saat Mengikuti Timbang Terima Perawat Ruang Bedah Pada Rs Negeri Di menyelesaikan pekerjaannya dan mampu memberikan pelayanan keperawatan syariah dengan baik.

\section{SIMPULAN}

Terdapat hubungan antara reward dan supervisi dengan pelaksanaan pelayanan keperawatan syariah. Hal ini dapat di implikasikan bahwa hasil penelitian hubungan reward dan supervisi dengan pelaksanaan pelayanan keperawatan syariah di RSI Sultan Agung Semarang, dapat dijadikan pertimbagan bagi pemangku kebijakan rumah sakit untuk meningkatkan reward para perawat yang menerapkan pelayanan keperawatan syariah dan meningkatkan pelaksanan supervisi dengan mempertahankan model supervisi ilmiah.

Semarang. Jurnal Manajemen Keperawatan, Vol 1 No. 2 hal. 95-99 http://jurnal.unimus.ac.id/index.php/JMK /article/viewFile/1004/1053

Kumajas, Marouw, Bawotong. (2014). Hubungan Karakteristik Individu Dengan Kinerja Perawat Di Ruang Rawat Inap Penyakit Dalam RSUD Datoe Binangkang Kabupaten Bolaang Mongondow, Jurnal Keperawatan. Vol 2 No. 2 https://ejournal.unsrat.ac.id/index.php/jkp /article/view/5304/4817

Majid A., dan Sani A. (2016). Pengaruh Pelatihan Dan Supervisi Kepala Ruangan Terhadap Kinerja Perawat Pelaksana Diruang Rawat Inap Bedah Rumah Sakit Pelamonia Makassar, Jurnal Mirai Management, Vol. 1 No. 2, Oktober 2016.

https://pdfs.semanticscholar.org/a0f3/111 0b3ce76d6ea52711ab220d2bcc0326c33. pdf

Marquis, B. L., \& Huston, C. J. (2009). Leadership roles and management functions in nursing: Theory and application. Lippincott Williams \& Wilkins.

MUKISI. (2017). Pedoman Standar Pelayanan Minimal Rumah Sakit Syariah Dan Indikator Mutu Wajib Syariah. Jakarta: Tidak Dipublikasi.

MUKISI. (2017). Standar \& Instrument Sertifikasi Rumah Sakit Syariah. Jakarta: Tidak Dipublikasi. 
Nursalam. (2015). Manajemen Keperawatan Aplikasi Dalam Praktik Keperawatan Professional. Jakarta: Salemba Medika.

Oktariana, E. (2009). Gambaran System Rekrutmen dan Seleksi Perawat di Rumah Sakit Haji Jakarta Untuk Mendukung Pelayanan Kesehatan Islami. [Skripsi]. Depok: Fakultas Kesehatan Masyarakat Universitas Indonesia.

Prestyaningtyas A. (2015). Analisis FaktorFaktor yang Berhubungan dengan Efektifitas Komunikasi Perawat dan Pasien di Ruang Rawat Inap RS Harapan Mulia Bekasi. Jurnal Administrasi Rumah Sakit, Vol. 2 No. 1 http://journal.fkm.ui.ac.id/arsi/article/vi ew/2190/728

Priyadi. (2015). Manajemen Rumah Sakit Menghadapi Era Masyarakat Ekonomi Asean Tahun 2015. Jakarta: http://www.indonesianqualityaward.org/b aldrige-berdasarkan-sektor/healthcare/manajemen-rumah-sakitmenghadapi-era-masyarakat-ekonomiasean-th-2015\#.VsCe4rR97Mw.

Rahayu S, Dewi E. (2017). Hubungan Antara System Reward dengan Kinerja Perawat dalam Melaksanakan Asuhan Keperawatan Di RSUD Sragen. Berita Ilmu Keperawatan. ISSN 1979-2697, Vol. 2 No. 2, Juni 2009: 51-56. http://journals.ums.ac.id/index.php/BIK/a rticle/view/3792/2452

Ravichandran. (2010). Influence of Service Quality on Customer Satisfaction. International Journal of Business and Management, Vol. 5, No. 4; April 2010.

Sari, Dyah Wiji Puspita, Abdurrouf, Rismawati. (2018). Pelayanan Keperawatan Berbasis
Syariah dan Loyalitas Pasien Di Rumah Sakit Islam Sultan Agung Semarang. Jurnal NURSCOPE, 2018, vol.8, No.3, hal $435-440$ http://jurnal.unissula.ac.id/index.php/jnm /article/view/3942/2802

Simamora. (2004). Panduan manajemen keperawatan. Jakarta: PT. Gramedia Pustaka Utama.

Singodimedjo \& Markum. (2009). Manajemen Sumber Daya Manusia. Surabaya: SMMAS.

Suyanto. (2008). Mengenal Kepemimpinan dan Manajemen Keperawatan di Rumah Sakit. Jogjakarta: Mitra Cendikia Jogjakarta.

Wawan, A dan Dewi, M. (2010). Teori dan Pengukuran Pengetahuan, Sikap dan Perilaku Manusia.. Yogyakarta: Nuha Medika.

Widiharti, L. (2016). Pengaruh Stres Kerja Terhadap Kepuasan Kerja Perawat Di Ruang Rawat Inap Rumah Sakit Krakatau Medika Cilegon. Jurnal Bisnis dan Investasi Volume 2, No.3, Desember 2016.

Wirawan, A., Novitasari, D., \& Wijayanti F. (2013). Hubungan antara supervisi kepala ruang dengan pendokumentasian asuhan keperawatan di RSUD Ambarawa. Jurnal Manajemen Keperawatan. Vol 1 No. 1 tahun 2013. https://jurnal.unimus.ac.id/index.php/JM K/article/view/943

Yanti, R. I., \& Warsito, B. E. (2013). Hubungan karakteristik perawat, motivasi, dan supervisi dengan kualitas dokumentasi proses asuhan keperawatan. Jurnal Manajemen Keperawatan, 1(2). 